\title{
Himalayan Nomenclature
}

\section{Author(s): Douglas W. Freshfield}

Source: The Geographical Journal, Vol. 24, No. 3 (Sep., 1904), pp. 356-359

Published by: geographicalj

Stable URL: http://www.jstor.org/stable/1776598

Accessed: 27-06-2016 16:33 UTC

\section{Your use of the JSTOR archive indicates your acceptance of the Terms \& Conditions of Use, available at}

http://about.jstor.org/terms

JSTOR is a not-for-profit service that helps scholars, researchers, and students discover, use, and build upon a wide range of content in a trusted digital archive. We use information technology and tools to increase productivity and facilitate new forms of scholarship. For more information about JSTOR, please contact support@jstor.org.

The Royal Geographical Society (with the Institute of British Geographers), Wiley are collaborating with JSTOR to digitize, preserve and extend access to The Geographical Journal 
north of Novaya Zemlya and the approach to Franz Josef Land and north-east Spitzbergen were blocked most of the summer. To the end of August polar ice was met between South cape and Horne sound. During the last days of August sailing vessels had no difficulty in navigating north of Seven islands, and thence all along the north-west and west coast of Spitzbergen there was open water throughout September. Along the east coast of Greenland the winter ice lay unbroken during the first half of August. The coasts of Iceland were free of ice throughout the year, save only for a short period in April and June in Skagastrand bay. Throughout the spring and summer of 1903 there was a heavier drift of icebergs than had been known for years before along the coasts of Labrador and Newfoundland, and as late as November an iceberg was seen at Newfoundland bank. An isolated floe was observed in August at $373^{\circ} \mathrm{N}$. and $71 \frac{1}{2}^{\circ} \mathrm{W}$. In Hudson strait icebergs were rather numerous, and floes somewhat more numerous than usual till the beginning of August. In Bering sea the eastern and the western passages both became available in the beginning of June, the strait being reached by both routes about June 20. The northward drift of ice in the strait ceased in the first half of July.

\section{GENERAL.}

The Population of the Earth.-In the latest issue of "Die Bevölkerung der Erde" (Pet. Mitt., Ergänzungsheft 146) Prof. Supan completes his survey of the population of the world about the beginning of the twentieth century by summarizing the results of recent censuses in Europe and Australia, afterwards giving a general table showing his estimate of the population of each of the continents, and of the aggregate for the whole world. The results are as follows:-

\begin{tabular}{lccc|c|c}
\hline & & & Total population. & $\begin{array}{c}\text { Per sq. } \\
\text { mile. }\end{array}$ \\
Europe & $\ldots$ & $\ldots$ & $\ldots$ & $392,264,000$ & 104 \\
Asia & $\ldots$ & $\ldots$ & $\ldots$ & $819,556,000$ & $46 \cdot 6$ \\
Africa & $\ldots$ & $\ldots$ & $\ldots$ & $140,700,000$ & 13 \\
Australia and & $\ldots 0 l y n e s i a$ & $6,483,000$ & 2 \\
North America & $\ldots$ & $\ldots$ & $105,714,000$ & 13 \\
South America & $\ldots$ & $\ldots$ & $38,482,000$ & 5 \\
Polar Lands & $\ldots$ & $\ldots$ & 91,000 & - \\
\hline Total & $\ldots$ & $\ldots$ & $1,503,300,000$ & 26 \\
\hline
\end{tabular}

\section{CORRESPONDENCE.}

\section{Himalayan Nomenclature.}

Some months ago I was able to report to your readers that His Excellency the Viceroy of India, acting on a suggestion I had ventured, had succeeded in obtaining permission from the Nepalese Government for an English survey officer to proceed to Katmandu in order to identify the peaks visible from the heights in the neighbourhood of that city, and, further, to ascertain what names, if any, were given to them respectively by the natives of Central Nepal. The particular objects of this inquiry were to discover whether (1) Peak XV. of the Survey, the highest 
measured mountain in the world, was visible from this quarter; (2) if visible, whether it had been accurately identified by the German travellers Dr. Schlagintweit and Dr. Boeck; and (3) to what summit or summits, if any, the name Gaurisankar was locally attached.

For the past controversy on these matters I must refer your readers to the list below.*

The results of the present inquiry have been as follows. $\dagger$ Peak XV. has been successfully identified and measured by Captain Wood from two heights near Katmandu. The late Surveyor-General, General Walker, and Colonel Waddell were therefore in error in maintaining that from this quarter it was not visible. The peak was seen, as I had predicted it would be, as a comparatively inconspicuous object over a gap in the nearer mountains. $\ddagger$ The inquiry has further proved that both $\mathrm{H}$. Schlagintweit and Dr. Boeck were wrong in their identification of it. (Schlagintweit's X.V. is really XX., Boeck's is XXIV., of the Survey.) 1 was wrong, therefore, in surmising that Boeck's XV. might be identified with XVIII., and in the consequent suggestion I made with respect to the position of Peak XV. in the panorama.

With regard to nomenclature, I must quote Captain Wood textually. "As regards the naming of the various peaks, I could discover nothing. The name Gaurisankar appears to be one given (by the nobles at Katmandu only) to the two highest peaks of the group which is the only conspicuous one seen from the city (the one marked as Gaurisankar on Schlagintweit's panorama is Peak XX.), and I very much doubt if they could recognize it if seen from a slightly different point of view. At least the officer His Excellency Maharaja Chandra Shamsher sent up to Kaulia to point out this peak to me failed to recognize it, and said it was not visible from there; and even after I had pointed out the peak to him, he said it was not Gaurisankar, but a peak something like it. Every lower-class native of the valley I asked did not know the peak by that or any other name, nor did they appear to give names to any of the snows at all. At Kaulia and at Mahadeo Pokra I had several -about ten in all-hillmen brought to me who were supposed to know the names of the hills, and every one, without exception, gave different names to the same peaks, and none called the peak known in the valley as Gaurisankar by that name. Very ntarly every other peak visible was pointed out as Gaurisankar when asked; but with the exception of two men, both at Kaulia, none gave the name Gaurisankar to any peak until they were asked which was Gaurisankar. My method of questioning was to lay a straight stick on the plane-table, and tell them to point it in succession to the hills whose names they knew. At first I took down the names they gave; but as each gave a different one, I did not think any reliance

* Alpine Journal, vol. xii. p. 438; vol. xxi. pp. 33, 317; vol. xxii.. p. 56.

Proceedings of R.G.S. (N.S.), vol. viii. pp. 88, 177, 257 ; xiii. p. 108.

Geographical Journal, vol. xxi. p. 294; xxiii. p. 89.

Petermanns Mitteilungen, vol. xxxiv. pt. 2; vol. xlvii. pt. 1, pt. 12 ; vol. xlviii. pt. 1.

'A Few Lines on Mount Everest.' By Colonel H. C. B 'Tanner. Calcutta: 1890.

'Round Kangchenjunga,' p. 199, and Appendix. By Douglas W. Freshfield.

'Among the Himalayas,' by L. A. Waddell, p. 345.

'Durch Indien in Verschlossenen Land Nepal,' Dr. K. Boeck, p. 314.

$\dagger$ 'Report on the Identification and Nomenclature of the Himalayan Peaks as seen from Katmandu, Nepal.' By Captain H. Wood, R.E. With Preface by Colonel St. G. Gore, C.s.I., R.E. Calcutta: 1904. 3s.

$\ddagger$ Geographical Journal, vol. xxiii. p. 89: "It will probably be found that the great peak, if visible at all, is far from conspicuous, and only recognizable-like the Finsteraarhorn from Grindelwald "- I had better have written from Milan-" to those who know where to look for it." 
could be put in them, and discontinued doing so. The two men mentioned above gave the name Gaurisankar, one to Peak XXIV. and the other to Peak XXVIII. Peak XXIV. is undoubtedly the one reproduced in the March Journal of the R.G.S. of 1903 from Dr. Boeck's work, and identified by Mr. Freshfield as Peak XVIII."

With this statement before my eyes, I can only express my amazement that the late Surveyor-General, Colonel Gore, should have commented on it in the following terms: "The whole evidence collected by Captain Wood is quite against the theory that Gaurisankar is a name given to the mountain mass of which Peak XX., which is the prominent point, is only one peak." As I read it, what Captain Wood's evidence proves is that the "nobles of Katmandu" call the snow summits they can see from the capital indifferently Gaurisankar, and that the hillmen are, when asked, ready to give that name to any peak visible.

Colonel Gore goes on, "There now remains the further question whether Peak XV. (Everest) can be called a peak of the group of which Peak XX. (Gaurisankar) is the most conspicuous as seen from Katmandu or its neighbourhood." "Everest," he writes, "which with Peak XIII. (Makalu) forms a separate group, stands 36 miles to the east of Peak XX., but separated from it by the upper end of the Dudh Kosi valley. The two groups are joined by a ridge running round to the north, over which the road passes by the Pangu-a" (la ?) "from the Dudh Kosi valley to Dingri; but to call these groups one and the same is to my mind quite untenable." Captain Wood is, on this point, even more emphatic. "Everest ... standing as it does quite apart from and a long way behind the main range, to call it a peak of the Gaurisankar group is absurd."

Colonel Gore has omitted to state that the so-called "road" in question is a glacier pass of over 20,000 feet, describ $₫$ d by the Pundit who crossed it as one of great difficulty. It is, therefore, according to the principles used hitherto in the definition of Alpine groups, no proper boundary for a group. Nor, with all due deference to Captain Wood, can I see anything absurd in giving to a Himalayan group an extension only equal to that of the Bernese Oberland from the Gemmi to the Grimsel.

But I desire to be perfectly fair, and I most readily admit that to take a name which is often loosely applied, but which when specifically applied appears, as a rule, to be given to a knot, or one of a knot, of summits at one end of a group, and to fasten it on a peak 36 miles off at the other end of the group, seems at first sight a strong proceeding. Still, had the surveyors done this, they would have had the precedent of the early map-makers of Savoy, who, until nearer approach revealed the name of Mont Blanc, were content to use the generic term 'la montagne maudite,' which was often affixed by the Genevese to the Buet, for all the snows south and north of the Chamonix valley. If they did not feel justified in doing this, the surveyors might surely have waited. To call the highest mountain in the world after one of its late chiefs may seem natural to a Department, but it will hardly persuade-it has not succeeded in persuading-the world to share its view.

The question, which from the first was one mainly of taste, has in India now become partly one of feeling. It is a question on which people are likely to hold, and are justified in maintaining, different opinions. But the circumstances have changed since 1856 - and even since 1886-and it seems to me no longer necessary to prolong the controversy, for the question has become an academical one. A local Tibetan name, Chomo-kankar, "The Lord of Snows," has been provided for Peak XV. on excellent native authority, confirmed by Colonel Waddell. By this the highest mountain, which stands on the frontier of Tibet, should in my opinion henceforth be designated by geographers. 
I do not wish to lengthen this note by personal matter beyond what may be absolutely needful, but I cannot pass by without correction one or two statements in the recent Report. Colonel Gore observes that I allege the point of my argument to be "whether the 29,002-feet peak is among the snows visible from Kakani and known as Gaurisankar." He goes on, "This to my mind begs the question." If he will once more consider the matter, he will see, I am sure, that such an inquiry was a necessary preliminary to any profitable discussion of the main question, whether the name Gaurisankar could be legitimately affixed to Peak XV. That question had been shelved on the erroneous assertion made by a late Surveyor-General, and repeated by Colonel Waddell, that Peak XV. was invisible from near Katmandu.

Captain Wood on his part has imperfectly catalogued and incorrectly summarized (pp. 2, 3, near top) my contributions to the discussion; moreover, my attitude throughout is misrepresented. I have desired not to endorse, but to investigate, the identifications of the German travellers. In 'Round Kangchenjunga' I expressly said, "I am not prepared to treat (Dr. Boeck's) identification as satisfactorily established." I have never treated Schlagintweit's identification as established, and Captain Wood, when he states the contrary, on the authority of Schlagintweit's brother, Dr. E. Schlagintweit, has been misled. What I wrote in 1886 was-

"I am very ready to allow that General Walker has shown that the Schlagintweits' identification requires confirmation. Both Mr. Hodgson and the Schlagintweits may prove to be altogether wrong."

Finally, I must quote textually the following sentence of Captain Wood's : "Sir A. Waugh proposed first to the Government of India and then to the Royal Geographical Society in London to give to this peak the name of his predecessor in office, because, though he had always scrupulously adhered to the rule of assigning to every geographical object its true local or native appellation, the Survey officers had not been able to discover, nor were they likely to be able to do so, any local name, and that as it was probably the highest mountain in the world, he had decided to name it after his late chief and to show that it was the peak alone that was so named and not the range he prefixed the word 'Mont,' and not Mount." *

Once more, it seems, I must repeat what ought to be common knowledge, that neither in Latin nor in French, nor in the local usage of the Alps bas Mons or Mont any significance beyond that of our English Mount, such as is bere alleged. Has Captain Wood never heard of the Mont Cenis, the Mont St. Gotthard, and the Mont d'Or? I have shown elsewhere $\dagger$ that Sir A. Waugh's use of "Mont" was probably a slip of the pen or the printer, and was not followed by contemporary authorities.

Douglas W. Freshfield.

* I leave the punctuation as in the original.

$\dagger$ Petermanns Mitteilungen, vol. xlviii.; Alpine Journal, vol. xxi. 